\title{
Child automobile restraints
}

\author{
Patricia P.S. Lee MD, Andrew W. Howard MD
}

\section{Guidance from physicians about child automobile restraints is im- portant for injury prevention}

Injuries from motor vehicle collisions are the leading cause of death among Canadian children. ${ }^{1}$ Well-child visits are a good time for physicians to provide information to parents on proper installation and use of car seats. Appropriate use of car seats can reduce the risk of death or serious injury by $67 \%-71 \%$. A guide based on best practices is shown in Appendix 1 (www.cmaj.ca/cgi/content/full /cmaj.101287/DC1).

Children four to nine years old should be in booster seats

A booster seat positions both child and seatbelt for optimal safety. A poorly positioned seatbelt can cause injuries to the abdominal organs, lumbar spine, spinal cord and head. A US cohort study involving 7151 children aged four to eight years showed that those placed in booster seats had a $45 \%$ lower risk of injury than those restrained by a seatbelt alone. ${ }^{3}$

\section{Young children should be placed in rear-facing car seats, preferably until age two to four years}

Many parents believe that young children can be placed in a forward-facing car seat once they reach $10 \mathrm{~kg}$ or one year of age. This places children at a high risk of injury and death because their neck muscles are too weak to withstand the force of even a low-speed collision. ${ }^{2}$ A cohort analysis in the United States involving 1841 children less than 24 months of age showed that children placed in forward-facing seats were $75 \%$ more likely to sustain serious injury than were children in rearfacing car seats. ${ }^{2}$

\section{The back seat is best for children under age 13}

A retrospective cohort analysis in Australia involving 30631 children aged less than 13 years showed that children placed in the front seat were $60 \%$ more likely to have a serious injury and two to four times more likely to die compared with children in the rear seat. ${ }^{4}$ The middle position in the back seat is preferred: in a cohort study in the United States involving 5358 children less than four years of age, the risk of injury was $43 \%$ lower among children seated there than among those sitting in the outer rear seats. ${ }^{5}$
Competing interests: Patricia Lee received a grant from MITACS for a student internship to undertake activities related to knowledge translation. No competing interests declared by Andrew Howard.

This article has been peer reviewed.

Affiliations: From the Department of Family Medicine (Lee), University of Western Ontario, London, Ont.; the Department of Surgery (Howard), University of Toronto, Toronto, Ont.; and Child Health Evaluative Sciences (Lee, Howard), Hospital for Sick Children, Toronto. Ont.

Correspondence to: Dr. Patricia P.S. Lee, patriciaps.lee@utoronto.ca

CMAJ 2011. DOI:10.1503/cmaj.101287
Parents can attend clinics to learn procedures for safe installation of car seats

Information about provincial child car seat clinics is available on the Transport Canada website (www .tc.gc.ca/eng/roadsafety/safedriverschildsafety-seat-clinics-1058.htm).

\section{References}

1. Canadian Paediatric Society. Transportation of infants and children in motor vehicles - position statement. Paediatr Child Health 2008;13:313-8.

2. Henary B, Sherwood CP, Crandall JR, et al. Car safety seats for children: rear facing for best protection. Inj Prev 2007;13:398-402.

3. Arbogast KB, Jermakian JS, Kallan MJ, et al. Effectiveness of belt positioning booster seats: an updated assessment. Pediatrics 2009;124:1281-6.

4. Lennon A, Siskind V, Haworth N. Rear seat safer: seating position, restraint use and injuries in children in traffic crashes in Victoria, Australia. Accid Anal Prev 2008;40:829-34.

5. Kallan MJ, Durbin D, Arbogast KB. Seating patterns and corresponding risk of injury among 0 - to 3 -year-old children in child safety seats. Pediatrics 2008;121:e1342-7.

CMAJ invites submissions to "Five things to know about ..." Submit manuscripts online at http://mc.manuscriptcentral .com/cmaj 